\title{
The role of metabolites in morphine analgesic effects
}

\begin{abstract}
Morphine is metabolized into two main metabolites, morphine-3-glucuronide and morphine-6-glucuronide. Morphine-6-glucuronide is a potent analgesic that is responsible for up to $97 \%$ of the analgesic effect. Morphine-3-glucuronide does not bind to opioid receptors and is devoid of any analgesic effect. However, it activates the Toll-like 4 receptors initiating neurogenic inflammation in the central nervous system. This, in turn, is responsible for anti-analgesic and hyperalgesic effects. There are a number of strategies on how to inhibit this pronociceptive effect and finally improve morphine analgesia.
\end{abstract}

Palliat Med Pract 2018; 12, 4: 198-202

Key words: pain, morphine metabolism, morphine-3-glucuronide, morphine-6-glucuronide, opioid receptors, analgesia, Toll-like 4 receptors

\section{Introduction}

Morphine as a drug isolated from opium is known in medicine for more than 200 years [1]. It is one of the most important and efficacious drugs used in pain treatment [2]. Slightly less well known is morphine's effect on breathlessness and diarrhoea. Morphine experienced its renaissance at the end of the past century when it became evident that it is, despite its shortcomings, a cheap, good and powerful drug for the treatment of cancer-related pain [3]. Earlier morphine was considered to be unable to reach sufficient concentrations in blood because of the first pass metabolism in the liver [4]. Tolerance and opioid-induced hyperalgesia [5] belong to the most feared features of morphine. The fact that morphine is metabolized to glucuronides is known for several decades [6]. However, the exact role of these metabolites in the morphine analgesia is still a matter of debate and uncertainty. The role of metabolites and strategies on how to influence their activity will be discussed in this paper.

\section{Pharmacology}

Morphine is a hydrophilic drug and it can be administered orally, subcutaneously, intravenously, intramuscularly, intrathecally, epidurally, and rectally. Additionally, nebulized morphine can be used in the treatment of breathlessness [7]. After parenteral administration, it penetrates easily to the central compartment and especially to the well-perfused organs. It is eliminated from the central compartment with the $T_{1 / 2}$ of 1.4-3.4 hours. Similar elimination $T_{1 / 2}$ is observed after oral, subcutaneous, intravenous, and intramuscular administration $[8,9]$.

After oral administration morphine is fully absorbed from the gut and transported to the liver, where it undergoes rapid metabolism to two main metabolites: morphine-3-glucuronide (M3G) and morphine-6-glu-

\footnotetext{
Adres do korespondencji:

Zbigniew Żylicz

Instytut Medycyny Doświadczalnej i Klinicznej,

Wydział Medyczny, Uniwersytet Rzeszowski

ul. Kopisto 2a, al. Kopisto 2a Rzeszów

e-mail: z.zylicz@ur.edu.pl
} 
curonide (M6G) [10]. The enzyme responsible for this, UGT2D7 metabolizes morphine in a constant proportion of M6G/M3G 1:9 [10]. Brain and other tissues may have variant enzymes, so we only assume that the proportion known from the liver metabolism is the same in all other tissues [11]. A small quantity of morphine is metabolised in the liver to normorphine by a CYP3A4 enzyme [12]. However, normorphine is a much weaker analgesic than morphine and does not appear to be toxic [13]. The overall bioavailability of morphine is variable and is approximately $20-30 \%$ [14]. The drug with this profile would never be licensed to be used in the $21^{\text {st }}$ century. The unpredictability of the bioavailability is reflected by the individual doses of morphine and the need of the dose titration until analgesia is achieved. Approximately $10 \%$ of the original dose is excreted unchanged with urine. The rest is excreted by the kidney as glucuronides and as other minor metabolites with the bile [15].

\section{Diffusion of morphine and its metabolites through the blood-brain barrier}

Morphine, as a hydrophilic drug, penetrates with difficulty through the blood-brain barrier in a paracellular mode [10]. This means, that the drug needs to accumulate considerably at the blood side to create enough gradient. Once in, some of the drug is actively pumped out by a P-glycoprotein [16]. Inhibition of this enzyme by a number of drugs and naturally occurring substances may increase morphine toxicity [17]. More hydrophilic metabolites cross the bloodbrain barrier with even greater difficulty. However, M6G is probably primarily actively transported into the brain by the endothelial Oatp2 protein $[18,19]$. This may explain M6G analgesic potency when given parenterally in the treatment of postoperative pain which is comparable to morphine itself [20]. Anyway, in the liquor part of the M6G originates from liver metabolism and part is synthesized de novo in the brain [21] Brain UGT2B7 glucuronidase appears in a number of variants [22] One of these variants occurs in the sickle cell disease and it causes decreased glucuronidation of morphine [23]. It explains why morphine is inefficacious in the pain crisis during this disease [24]. Naloxone, which crosses the blood-brain barrier abolishes fully morphine analgesia, while the naloxone derivatives which do not cross the bloodbrain barrier show no effect.

M6G administered systemically in humans has an analgesic potency roughly equal to those of morphine [20]. However, the same drug administered intracerebrally in rats is 100 times more potent than morphine [25]. In the first hours, systemically administered morphine is more potent compared to systemically administered M6G. This is probably due to slow diffusion through the blood-brain barrier. The cycle morphine-diffusion-metabolism in the brain to M6G is faster than the diffusion of M6G. It is estimated that $91-97 \%$ of the analgesic effect of morphine is due to M6G [26] and morphine can be seen as a pro-drug. However, in the case of renal insufficiency M6G will accumulate and can be toxic or even lethal $[27,28]$. Renal function declines with age and at the age of 90 years, it is only half of the original value in children [29]. This is also the reason why children and adolescents need higher morphine doses in comparison to the geriatric population.

\section{The role of morphine-3-glucuronide in pain treatment}

M3G does not bind to any opioid receptor and is devoid of any analgesic effect [30]. In a very high dose, $30 \mathrm{mg} \mathrm{IV}$, administered to healthy subjects it did not show any pharmacological effect [31]. It does not cross the blood-brain barrier.10 Plasma concentrations of M3G increase in renal insufficiency [32]. And yet, M3G for many years has been suspected to act antagonistically to morphine, and to induce opioid-induced hyperalgesia [33, 34]. A long search revealed its binding to the Toll-Like 4 receptors (TLR4) on the microglial cells and on macrophages [35-37]. TLR4 is one of many Toll-like receptors that organize an innate immune response reacting to foreign and endogenous harmful impulses, most often bacterial lipopolysaccharides (LPS) [38]. TLR4 is the key factor for all processes that for many years were collectively named neurogenic inflammation [39, 40]. These receptors bind a wide range of drugs and are not stereoselective [41]. Recently, TLR4 were considered to be crucial for understanding the emergence of many diseases, such as neurodegenerative, autoimmune, infectious and/or neoplastic diseases [42-44], as well as chronic pain [45]. M3G activates TLR4 as comparably to the bacterial-derived lipopolysaccharides (LPS) [46] Activation of TLR4 increases production of inflammatory cytokines: TNF- $\alpha, \mathrm{IL}-1 \beta, \mathrm{IL}-6$ and IFN- $\gamma 45$ and prostaglandins [47]. TLR4 explain different phenomena such as tolerance, hyperalgesia, pruritus, and cough $[47,48]$.

\section{Strategies to overcome Toll-like 4 receptors activation}

TLR4 inhibition with normally inactive on the opioid receptors (+)-naloxone, results in the abolition of 
morphine tolerance [47]. Moreover, treatment with (+)-naloxone greatly improved morphine analgesia in a rat nerve constriction model $[49,50]$. It is not surprising that TLR4 has become an important target for new drugs [51]. Glucocorticoids have been shown to block certain genes involved in the activation of TLR4 [52]. Tricyclic antidepressants and selective serotonin reuptake inhibitors (SSRI) are known for their role in inhibition of Toll-like receptors and may be used to improve analgesic effects of opioids [53].

\section{Summary}

Morphine metabolism to two main metabolites M3G and M6G has been known for decades. The implications of this metabolism for pain treatment became apparent only recently. Morphine, in fact, is a pro-drug which needs to be glucuronidated to M6G and act in the spinal cord and brain. Part of this process starts already in the liver, during the first pass metabolism. Morphine crosses the blood-brain barrier easier than M6G but M6G can be actively transported by Oatp2 and by de novo synthesis of M6G from morphine in the brain. Those mechanisms together make it possible that $\mathrm{M} 6 \mathrm{G}$ is the main analgesic, responsible for up to $97 \%$ of morphine analgesic effect.

The second metabolite, M3G usually seen as inactive and less important is the agonist to the TLR4 responsible for neurogenic inflammation in the brain. As such this process is antagonizing M6G analgesia and is involved in such phenomena as opioid-induced hyperalgesia, and opioid tolerance. There is a number of drugs that inhibit activation of TLR4 and pro-nociceptive effects of M3G. Among them are corticosteroids, tricyclic antidepressants and SSRI. Some of them are used for this purpose already for decades. However, it is conceivable that soon a series of new drugs specifically designed to antagonize TLR4 but not binding to opioid receptors may become available.

\section{References}

1. Schmitz R. Friedrich Wilhelm Sertürner and the discovery of morphine. Pharm Hist. 1985; 27(2): 61-74, indexed in Pubmed: 11611724.

2. Wiffen PJ, Wee $B$, Moore RA. Oral morphine for cancer pain. Cochrane Database Syst Rev. 2016; 4: CD003868, doi: 10.1002/14651858.CD003868.pub4, indexed in Pubmed: 27105021.

3. WHO. Cancer Pain Relief. Geneva. 1986

4. Berkowitz BA. The relationship of pharmacokinetics to pharmacological activity: morphine, methadone and naloxone. Clin Pharmacokinet. 1976; 1(3): 219-230, doi: 10.2165/00003088-197601030-00004, indexed in Pubmed: 13957.

5. Yi P, Pryzbylkowski P. Opioid Induced Hyperalgesia. Pain Med. 2015; 16 Suppl 1: S32-S36, doi: 10.1111/pme.12914, indexed in Pubmed: 26461074.
6. Säwe J, Svensson JO, Rane A. Morphine metabolism in cancer patients on increasing oral doses--no evidence for autoinduction or dose-dependence. Br J Clin Pharmacol. 1983; 16(1): 85-93, indexed in Pubmed: 6882627.

7. Janowiak P, Krajnik M, Podolec Z, et al. Dosimetrically administered nebulized morphine for breathlessness in very severe chronic obstructive pulmonary disease: a randomized, controlled trial. BMC Pulm Med. 2017; 17(1): 186, doi: 10.1186/s12890-017-0535-y, indexed in Pubmed: 29228935.

8. Glare PA, Walsh TD. Clinical pharmacokinetics of morphine. Ther Drug Monit. 1991; 13(1): 1-23, indexed in Pubmed: 2057987.

9. Lugo RA, Kern SE. Clinical pharmacokinetics of morphine. J Pain Palliat Care Pharmacother. 2002; 16(4): 5-18, indexed in Pubmed: 14635822.

10. De Gregori S, De Gregori M, Ranzani GN, et al. Morphine metabolism, transport and brain disposition. Metab Brain Dis. 2012; 27(1): 1-5, doi: 10.1007/s11011-011-9274-6, indexed in Pubmed: 22193538.

11. Sverrisdóttir $E$, Lund $T M$, Olesen $A E$, et al. A review of morphine and morphine-6-glucuronide's pharmacokineticpharmacodynamic relationships in experimental and clinical pain. Eur J Pharm Sci. 2015; 74: 45-62, doi: 10.1016/j. ejps.2015.03.020, indexed in Pubmed: 25861720.

12. Projean $D$, Morin $P E$, Tu TM, et al. Identification of $C Y$ P3A4 and CYP2C8 as the major cytochrome P450 s responsible for morphine $\mathrm{N}$-demethylation in human liver microsomes. Xenobiotica. 2003; 33(8): 841-854, doi: 10.1080/0049825031000121608, indexed in Pubmed: 12936704.

13. Nagamatsu K, Ohno $Y$, Ikebuchi $H$, et al. Morphine metabolism in isolated rat hepatocytes and its implications for hepatotoxicity. Biochem Pharmacol. 1986; 35(20): 3543-3548, indexed in Pubmed: 2429666.

14. Hasselström J, Säwe J. Morphine pharmacokinetics and metabolism in humans. Enterohepatic cycling and relative contribution of metabolites to active opioid concentrations. Clin Pharmacokinet. 1993; 24(4): 344-354, doi: 10.2165/00003088-199324040-00007, indexed in Pubmed: 8491060 .

15. Hasselström J, Eriksson S, Persson A, et al. The metabolism and bioavailability of morphine in patients with severe liver cirrhosis. Br J Clin Pharmacol. 1990; 29(3): 289-297, indexed in Pubmed: 2310653.

16. Boström $E$, Hammarlund-Udenaes M, Simonsson USH. Blood-brain barrier transport helps to explain discrepancies in in vivo potency between oxycodone and morphine. Anesthesiology. 2008; 108(3): 495-505, doi: 10.1097/ALN.0b013e318164cf9e, indexed in Pubmed: 18292687.

17. Dewanjee S, Dua TK, Bhattacharjee N, et al. Natural Products as Alternative Choices for P-Glycoprotein (P-gp) Inhibition. Molecules. 2017; 22(6), doi: 10.3390/molecules22060871, indexed in Pubmed: 28587082.

18. Sattari $\mathrm{M}$, Routledge $\mathrm{Pa}$, Mashayekhi So. The influence of active transport systems on morphine -6-glucuronide transport in MDCKII and MDCK-PGP cells. Daru. 2011; 19(6): 412-416, indexed in Pubmed: 23008686.

19. Bourasset F, Cisternino S, Temsamani J, et al. Evidence for an active transport of morphine-6-beta-d-glucuronide but not P-glycoprotein-mediated at the blood-brain barrier. J Neurochem. 2003; 86(6): 1564-1567, indexed in Pubmed: 12950465.

20. Binning AR, Przesmycki K, Sowinski $P$, et al. A randomised controlled trial on the efficacy and side-effect profile (nausea/vomiting/sedation) of morphine-6-glucuronide versus morphine for post-operative pain relief after major 
abdominal surgery. Eur J Pain. 2011; 15(4): 402-408, doi: 10.1016/j.ejpain.2010.09.007, indexed in Pubmed: 21041105.

21. Meineke I, Freudenthaler S, Hofmann U, et al. Pharmacokinetic modelling of morphine, morphine-3-glucuronide and morphine-6-glucuronide in plasma and cerebrospinal fluid of neurosurgical patients after short-term infusion of morphine. Br J Clin Pharmacol. 2002; 54(6): 592-603, indexed in Pubmed: 12492606.

22. Schmid HP, Gregorin J, Altwein JE. Growth hormone inhibitors in prostate cancer: a systematic analysis. Urol Int. 2008; 81(1): 17-22, doi: 10.1159/000137635, indexed in Pubmed: 18645266.

23. Innocenti $F$, Liu $W$, Fackenthal $D$, et al. Single nucleotide polymorphism discovery and functional assessment of variation in the UDP-glucuronosyltransferase 2B7 gene. Pharmacogenet Genomics. 2008; 18(8): 683-697, doi: 10.1097/FPC.0b013e3283037fe4, indexed in Pubmed: 18622261.

24. Darbari DS, Minniti CP, Rana S, et al. Pharmacogenetics of morphine: Potential implications in sickle cell disease. Am J Hematol. 2008; 83(3): 233-236, doi: 10.1002/ajh.21027, indexed in Pubmed: 17722074.

25. Paul D, Standifer KM, Inturrisi CE, et al. Pharmacological characterization of morphine- 6 beta-glucuronide, a very potent morphine metabolite. J Pharmacol Exp Ther. 1989; 251(2): 477-483, indexed in Pubmed: 2810109.

26. Klimas R, Mikus G. Morphine-6-glucuronide is responsible for the analgesic effect after morphine administration: a quantitative review of morphine, morphine-6-glucuronide, and morphine-3-glucuronide. Br J Anaesth. 2014; 113(6): 935-944, doi: 10.1093/bja/aeu186, indexed in Pubmed: 24985077.

27. Bodd E, Jacobsen $D$, Lund E, et al. Morphine-6-glucuronide might mediate the prolonged opioid effect of morphine in acute renal failure. Hum Exp Toxicol. 1990; 9(5): 317-321, doi: 10.1177/096032719000900509, indexed in Pubmed: 2261246.

28. Hanna MH, D'Costa F, Peat SJ, et al. Morphine-6-glucuronide disposition in renal impairment. $\mathrm{Br} J$ Anaesth. 1993; 70(5): 511-514, indexed in Pubmed: 8318321.

29. Leierer J, Rudnicki M, Braniff SJ, et al. Metallothioneins and renal ageing. Nephrol Dial Transplant. 2016; 31(9): 1444-1452, doi: $10.1093 /$ ndt/gfv451, indexed in Pubmed: 26908771.

30. Pasternak GW, Bodnar RJ, Clark JA, et al. Morphine-6-glucuronide, a potent mu agonist. Life Sci. 1987; 41(26): 2845-2849, indexed in Pubmed: 2826951.

31. Penson RT, Joel SP, Clark $S$, et al. Limited phase I study of morphine-3-glucuronide. J Pharm Sci. 2001; 90(11): 1810-1816, indexed in Pubmed: 11745739.

32. Sear JW, Hand CW, Moore RA, et al. Studies on morphine disposition: influence of renal failure on the kinetics of morphine and its metabolites. Br J Anaesth. 1989; 62(1): 28-32, indexed in Pubmed: 2644963.

33. Smith MT, Watt JA, Cramond T. Morphine-3-glucuronide-a potent antagonist of morphine analgesia. Life Sci. 1990; 47(6): 579-585, indexed in Pubmed: 2402182.

34. Gong QL, Hedner J, Björkman R, et al. Morphine-3-glucuronide may functionally antagonize morphine-6-glucuronide induced antinociception and ventilatory depression in the rat. Pain. 1992; 48(2): 249-255, indexed in Pubmed: 1589243.

35. Lewis SS, Hutchinson MR, Rezvani N, et al. Evidence that intrathecal morphine-3-glucuronide may cause pain enhancement via toll-like receptor 4/MD-2 and interleukin-1 beta. Neuroscience. 2010; 165(2): 569-583, doi: 10.1016/j. neuroscience.2009.10.011, indexed in Pubmed: 19833175.
36. Hutchinson MR, Lewis SS, Coats $B D$, et al. Possible involvement of toll-like receptor 4 /myeloid differentiation factor-2 activity of opioid inactive isomers causes spinal proinflammation and related behavioral consequences. Neuroscience. 2010; 167(3): 880-893, doi: 10.1016/j. neuroscience. 2010.02.011, indexed in Pubmed: 20178837.

37. Hutchinson MR, Northcutt AL, Hiranita $T$, et al. Opioid activation of toll-like receptor 4 contributes to drug reinforcement. J Neurosci. 2012; 32(33): 11187-11200, doi: 10.1523/JNEUROSCI.0684-12.2012, indexed in Pubmed: 22895704

38. Matzinger $P$. The danger model: a renewed sense of self. Science. 2002; 296(5566): 301-305, doi: 10.1126/science.1071059, indexed in Pubmed: 11951032.

39. Steinhoff M, Ständer S, Seeliger S, et al. Modern aspects of cutaneous neurogenic inflammation. Arch Dermatol. 2003; 139(11): 1479-1488, doi: 10.1001/archderm.139.11.1479, indexed in Pubmed: 14623709.

40. Richardson JD, Vasko MR. Cellular mechanisms of neurogenic inflammation. J Pharmacol Exp Ther. 2002; 302(3): 839-845, doi: 10.1124/jpet.102.032797, indexed in Pubmed: 12183638

41. Moresco EM, LaVine D, Beutler B. Toll-like receptors. Curr Biol. 2011; 21(13): R488-R493, doi: 10.1016/j. cub.2011.05.039, indexed in Pubmed: 21741580 .

42. Zhang K, Zhou B, Wang Y, et al. The TLR4 gene polymorphisms and susceptibility to cancer: a systematic review and meta-analysis. Eur J Cancer. 2013; 49(4): 946-954, doi: 10.1016/j.ejca.2012.09.022, indexed in Pubmed: 23084080 .

43. Płóciennikowska A, Hromada-Judycka A, Borzęcka K, et al. Co-operation of TLR4 and raft proteins in LPS-induced pro-inflammatory signaling. Cell Mol Life Sci. 2015; 72(3): 557-581, doi: 10.1007/s00018-014-1762-5, indexed in Pubmed: 25332099.

44. Liu Yu, Yin H, Zhao M, et al. TLR2 and TLR4 in autoimmune diseases: a comprehensive review. Clin Rev Allergy Immunol. 2014; 47(2): 136-147, doi: 10.1007/s12016013-8402-y, indexed in Pubmed: 24352680.

45. Guo LH, Schluesener HJ. The innate immunity of the central nervous system in chronic pain: the role of Toll-like receptors. Cell Mol Life Sci. 2007; 64(9): 1128-1136, doi: $10.1007 / \mathrm{s} 00018-007-6494-3$, indexed in Pubmed: 17440679 .

46. Hutchinson MR, Zhang $Y$, Shridhar $M$, et al. Evidence that opioids may have toll-like receptor 4 and MD-2 effects. Brain Behav Immun. 2010; 24(1): 83-95, doi: 10.1016/j. bbi.2009.08.004, indexed in Pubmed: 19679181.

47. Grace PM, Ramos KM, Rodgers KM, et al. Activation of adult rat CNS endothelial cells by opioid-induced toll-like receptor 4 (TLR4) signaling induces proinflammatory, biochemical, morphological, and behavioral sequelae. Neuroscience. 2014; 280: 299-317, doi: 10.1016/j.neuroscience.2014.09.020, indexed in Pubmed: 25241065.

48. Ji RR. Neuroimmune interactions in itch: Do chronic itch, chronic pain, and chronic cough share similar mechanisms? Pulm Pharmacol Ther. 2015; 35: 81-86, doi: 10.1016/j. pupt.2015.09.001, indexed in Pubmed: 26351759.

49. Lewis SS, Loram LC, Hutchinson MR, et al. (+)-naloxone, an opioid-inactive toll-like receptor 4 signaling inhibitor, reverses multiple models of chronic neuropathic pain in rats. J Pain. 2012; 13(5): 498-506, doi: 10.1016/j.jpain.2012.02.005, indexed in Pubmed: 22520687.

50. Mika J. Modulation of microglia can attenuate neuropathic pain symptoms and enhance morphine effectiveness. Pharmacol Rep. 2008; 60(3): 297-307, indexed in Pubmed: 18622054. 
51. Peri F, Piazza M. Therapeutic targeting of innate immunity with Toll-like receptor 4 (TLR4) antagonists. Biotechnol Adv. 2012; 30(1): 251-260, doi: 10.1016/j.biotechadv.2011.05.014, indexed in Pubmed: 21664961.

52. O'Neill LAJ. Targeting signal transduction as a strategy to treat inflammatory diseases. Nat Rev Drug Discov. 2006; 5(7): 549-563, doi: 10.1038/nrd2070, indexed in Pubmed: 16773072.
53. Hutchinson MR, Loram LC, Zhang Y, et al. Evidence that tricyclic small molecules may possess toll-like receptor and myeloid differentiation protein 2 activity. Neuroscience. 2010; 168(2): 551-563, doi: 10.1016/j.neuroscience.2010.03.067, indexed in Pubmed: 20381591. 